\title{
In Vitro Test Systems for the Evaluation of the Estrogenic Activity of Natural Products
}

\author{
Patrick Diel ${ }^{*}$, Kai Smolnikar, and Horst Michna \\ Institut für Experimentelle Morphologie, Deutsche Sporthochschule Köln, Germany \\ Received: June 8, 1998; Accepted: September 13, 1998
}

\begin{abstract}
Many compounds of plant origin with the ability to bind to the estrogen receptor have been identified in the last decades. There is evidence that the consumption of some of these phytoestrogens may have beneficial effects but it also seems possible that others may act as endocrine disrupters. For this reason there is a need to characterise the estrogenic potency of these substances. In vitro test systems offer the possibility to screen compounds very efficiently. Routinely in use and widespread for the determination of estrogenicity are: (I) receptor binding assays, (II) cell-proliferation assays (Escreens), (III) reporter gene assays, and (IV) the analysis of the regulation of endogenous estrogen sensitive genes in cell lines. The basis of all these test systems are molecular mechanisms which are involved in the classical estrogen action. In addition, in the last years several test systems for the investigation of non-classical estrogenic effects have been established. An example for such an effect is the modulation of the expression of interleukin-6, a cytokine that appears to be a key molecule in the osteoporotic process, by estrogens. Summarising the advantages and the issues of all presented in vitro test systems, it seems to be evident that only the analysis of results obtained in a combination of several in vitro test systems may validly predict effcts in vivo.
\end{abstract}

Key words: Estrogens, phytoestrogens, interleukin-6, reporter gene assay, MCF-7 cell, E-screen.

$\begin{array}{ll}\text { Abbreviations: } \\ \text { ER: } & \text { estrogen receptor } \\ \text { ERE: } & \text { estrogen responsive element } \\ \text { NFKB: } & \text { nuclear factor kappa b } \\ \mathrm{K}_{\mathrm{D}}: & \text { dissociation constant } \\ \mathrm{MTT}: & \text { 3-[4,5-dimethylthiazol-2-yl]-2,5-diphenyltetrazolium } \\ & \text { bromide } \\ \text { PCR: } & \text { polymerase chain reaction } \\ \text { IL-6: } & \text { interleukin } 6 \\ \text { IL-1: } & \text { interleukin } 1 \\ \text { BrdU: } & \text { 5-bromo-2'-deoxyuracil }\end{array}$

Planta Medica 65 (1999) 197-203

(C) Georg Thieme Verlag Stuttgart · New York

\section{Introduction}

In the last decades in more than 300 different plants (1) chemicals have been identified which bind to the estrogen receptor and may induce many mechanisms of estrogen action. The most potent of these naturally occurring estrogens, also called phytoestrogens, are the isoflavonoids, diphenolic chemicals detected in the bean subfamily of Leguminosae. Even if the potency of the most of these natural estrogens is low compared to endogenous or synthetic estrogens like $17 \beta$-estradiol or ethinylestradiol, significant quantities of these non-steroidal estrogens are detectable in human urine (2). Epidemiologic data suggest that on the one hand the consumption of these environmental estrogens may have beneficial effects like protection for breast and prostate cancer $(3,4)$. On the other hand there is the possibility that these compounds may act as endocrine disrupters which could affect the endocrine system and may cause developmental $(5,6)$ and reproductive disturbances $(7,8)$. For this reason there is a need to characterise the hormonal potency of natural compounds with the ability to bind to the estrogen receptor. A lot of animal and in vitro test systems have been developed in the last decades to determine the estrogenic potency of synthetic compounds. These systems are also suitable to detect and quantify estrogenicity of natural products. In this review a survey of some of the in vitro test systems which are most commonly used in drug development these days will be given. Finally the possibilities of these systems, their issues and limitations will also be displayed.

\section{Physiology of Estrogen Action}

In the classical definition estrogens are steroid hormones with important functions regulating sexual specific processes in the female organism. Therefore, the highest amounts of estrogen receptors (ER) are found in the target tissues with reproductive functions. These target organs are the mammary gland, the ovaries, the vagina and the uterus. In these tissues estradiol stimulates the cell proliferation and the biosynthesis of the progesterone receptor (9). In the male organism ER can be detected in the epididymis and the prostate. In addition, there is knowledge about the action of estrogens in other, not classical target tissues like the brain, the bone, the cardiovascular system, the kidney, the immune system and the liver (Table 1). Estrogen deficiency seem to be involved in many pathologic processes like arteriosclerosis (10), osteoporosis 


\begin{tabular}{ll}
\hline Classical targets & Non-classical targets \\
\hline - Ovary & - Kidney \\
- Vagina & - Islets of Langerhans \\
- Uterus & - Liver \\
- Mammary gland & - Bone \\
- Adrenal gland & - Cardiovascular system \\
- Prostate & - Macrophages \\
- Pituitary gland & - Thymocytes \\
- Hypothalamus & - Lymphoid cells \\
- Leydig cells & - Endothelial cells \\
& - Osteoblastic cells \\
& - Glia cells \\
& - Schwann cells
\end{tabular}

Table 1 Estrogen sensitive tissues and cells.

(11) and degenerative processes in the CNS (12), whereas elevated estrogen levels are believed to support the development and promotion of tumors (13).

\section{Molecular Mechanisms of Estrogen Action}

The molecular mechanisms of estrogen action are the basis for the development of in vitro test systems. Therefore, a short survey about these mechanisms should be given here. The classical concept of the action of steroid hormone receptors was established by Jensen in 1968 (14, 15). The protein structure of steroid hormone receptors, their biochemical properties and the molecular mechanisms of their action have been intensively characterised in the last 25 years. Therefore, the classical concept has to be modified in many aspects (Fig. 1). After cytoplasmatic translation of the ER it is rapidly transfered to the nucleus (16), where it is stored in an inactive but primed state until a proper stimulus is received. The priming step is accomplished by association of the estrogen receptor with a variety of heat shock proteins, including hsp 90 and hsp 56 (17). This complex of the estrogen receptor and heat shock proteins rapidly dissociates after binding to a hormone. Here, it has to be mentioned that the mechanism of activation, long believed to be hormone dependent, is in question due to the observation that ER-mediated activity can be induced by signal transduction pathways. Growth factors like epidermal growth factor (EGF) and other members of
cAMP mediated signal transduction pathways are able to activate estrogen receptors without binding to a hormone. These mechanisms are defined as so-called cross talk mechanisms (18). After the activation protein-protein interactions between ER monomers to form homodimers occur. These dimers of ER have been reported to be required for high affinity DNA-binding (19). The receptor interacts via specific DNA-binding domains with ER binding sides, the estrogen receptor responsive elements (EREs) in the promotor region of sensitive genes. This binding leads to an initiation of transcription: initiating the hormonal effect (20). The organisation in functional domains like the DNA-binding domain, the hormone binding domain and the transactivation domains has been demonstrated to be highly conserved $(21,22)$. Today it is known that the action of steroid hormone receptors on the initiation of the transcription of sensitive genes can be modulated by a number of parameters. Relevant mechanisms are: the release of the ER from the priming complex $(18,22,23)$, the translocation of the ER in the nucleus (24), dimerisation of the ER (25), interaction of the ER with the transcription machinery $(26,27)$, chromatin/ER interactions (28), phosphorylation of the ER $(29,30)$, interaction of the ER with other transcription factors (31), cross talk with other signal transduction pathways (32), and mechanisms of deactivation and the recycling of the ER (33). Recent results in steroid hormone research like the observation of a tissue specific action of estrogens could only be explained if these complex molecular mechanisms are considered. In addition, there is increasing evidence that estrogens can act via a so-called non-transcriptional signaling pathway without involvement of the ER and transcriptional processes. An example is the action of estrogen on the excitability of nerve cells (34). In general, it seems that the term estrogenicity has to be defined in a much more complex manner as it was 25 years ago. This fact has to be considered if we discuss the validation and the suitability of a test system to predict the real estrogenicity of a substance.

\section{In Vitro Test Systems for the Prediction of Estrogenicity}

The most commonly used in vitro test systems for the prediction of estrogenicity are mainly suitable for the detection of classical estrogen mediated effects. Routinely in use

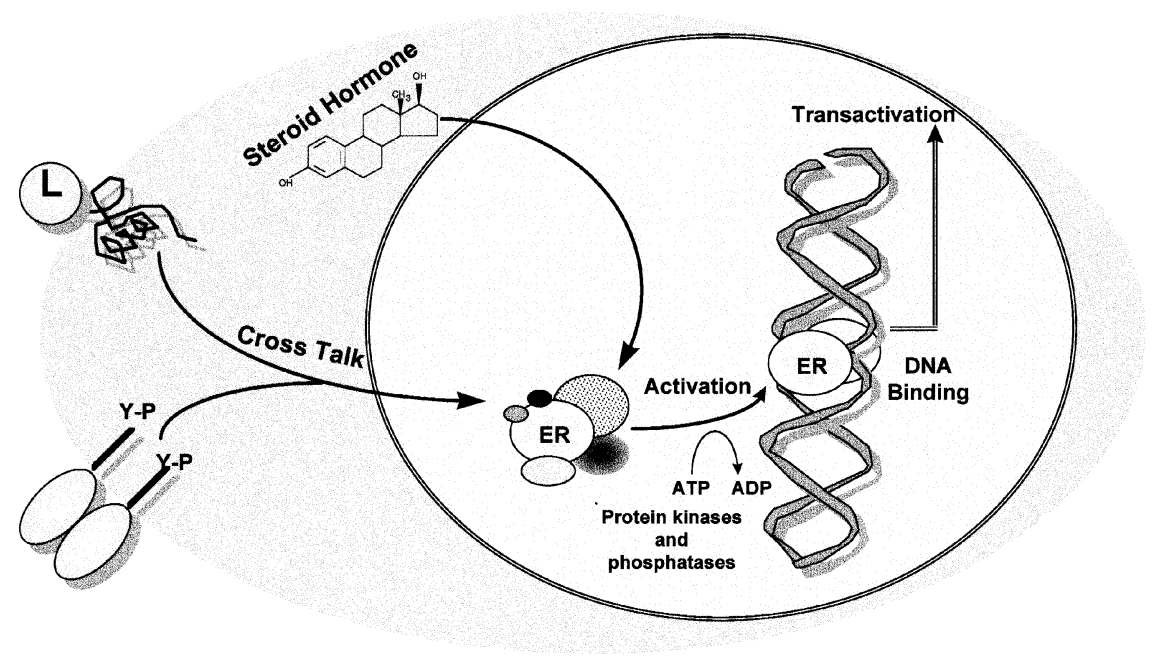

Fig. 1 Mechanisms of estrogen receptor activation. 
and widespread are: (I) receptor binding assays, test systems where the binding affinity of a compound to the estrogen receptor is determined; (II) cell-proliferation assays (Escreens), in this type of assay the proliferation stimulating potency of a substance is studied in an estrogen dependent cell line. This kind of assay is intensively used these days for the characterisation of natural substances. (III) Reporter gene assays, in this model the ability of a substance to activate the transcription of an estrogen sensitive promotor is analysed. Such assays are performed either in mammalian cell lines or yeasts. (IV) The analysis of the regulation of endogenous estrogen sensitive genes in cell lines (Table 2 ). Beside these test systems there are a lot of other possibilities to predict the estrogenicity of substances especially in regard to mechanistic aspects. For example, gel shift assays are used to investigate the ability of a receptor-ligand complex to bind to the DNA. In addition, in the last years several test systems have been established which offer the possibility to investigate the potency of a substance to induce non-classical estrogenic effects, for example on the bone or in the cardiovascular system. An example for such test systems will be given at the end of this review. There are also test systems available in which estrogen-like effects can be measured which are not mediated via the ER.

Table 2 In vitro test systems for the detection of estrogenicity.

- Receptor binding assay
Analysis of the binding affinity of a substance to the estrogen
receptor
- E-screen
Analysis of the ability of a substance to stimulate growth of
estrogen sensitive cells
- Reporter gene assay
Analysis of the ability of a substance to stimulate the transcription
of a reporter gene construct in cell culture
- Analysis of gene expression
Analysis of the ability of a substance to induce the mRNA
expression of estrogen sensitive genes in cell culture

\section{The Receptor Binding Assay}

The determination of the binding affinity of a ligand to its receptor is a classical concept of the pharmacological characterisation of a substance. These assays are part of the standard analysis in drug finding programs in many companies and can be performed by laboratory robots in the high throughput drug screen. The principle of the assay (35) is the determination of the binding affinity of a compound to a receptor: The dissociation constant $K_{\mathrm{D}}$ is defined as the concentration of the ligand where half of the available binding sides are saturated by the ligand (Fig. 2). For this reason the $K_{\mathrm{D}}$ is an indication for the binding affinity of a substance to the receptor. To perform a receptor binding assay in a first step a cytosolic extract from ER-rich tissue, normally the uterus, is prepared. A suitable volume of this extract is incubated with radioactive labelled hormones (36) and substances. In order to measure the affinity of a non-radioactive ligand, the test substance, the inhibition of the binding of the radioactive ligand is measured in a competition test. Some representative binding curves and the resulting $K_{\mathrm{D}} \mathrm{s}$ of three substances are shown in Figure 2. The receptor binding assay is an important

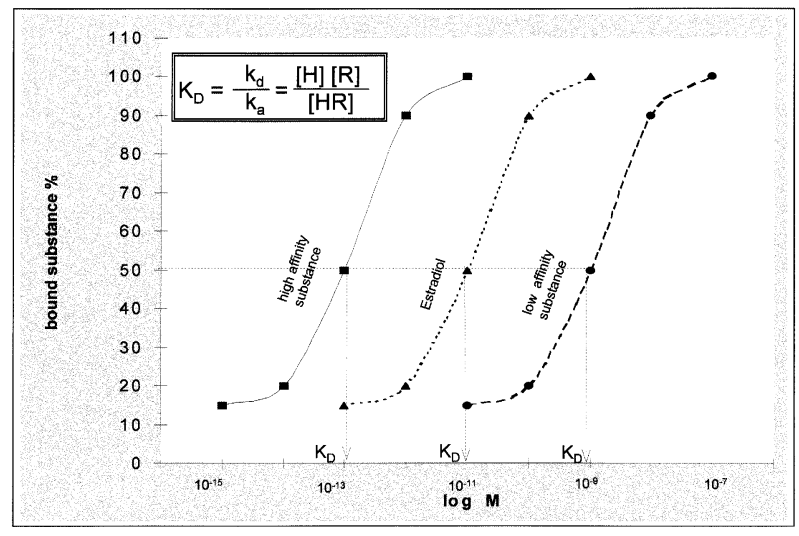

Fig. 2 Representative binding curves of three estrogenic substances in a receptor binding assay. $K_{\mathrm{D}}$ is the dissociation constant (in $\mathrm{M}^{-1}$ ) at equilibrium, $\mathrm{k}_{\mathrm{a}}$ is the association rate constant (in $\mathrm{M}^{-1}$ $\sec ^{-1}$ ). $K_{d}$ is the dissociation rate constant (in $\sec ^{-1}$ ), $[\mathrm{H}]$ is the concentration of free hormone (in $M$ ), $[R]$ is the concentration of free receptor sites.

method to determine the binding affinity of a substance to a receptor. Nevertheless, the assay does not provide any information in regard to estrogen activity, since just the binding to the receptor cannot distinguish between agonistic and antagonistic actions of a substance. The binding of a substance with a high binding affinity to the receptor must not result in its activation. Some compounds can block the biological activity of the receptor by an inhibition of the dimerisation or by preventing the binding of the receptordimer to the DNA. These compounds act as antagonists. Examples for estrogen antagonists are non steroidal antiestrogens like tamoxifen, or steroidal compounds like ZM 182780. In this context it should also be appropriate to consider alternative mechanisms for estrogen action like cross talk. Therefore, there is the possibility that a substance with no binding affinity to the ER may activate genes stimulating estrogen like reactions.

\section{E-Screen}

The E-screen is a widely used assay to determine the estrogenic potency of natural and environmental compounds (37). In these in vitro test systems the ability of a substance to stimulate the growth of estrogen dependent cell lines is measured. Most commonly, estrogen dependent human breast cancer cell lines like MCF-7 or T47-D are used. To measure the proliferation of a cell population either the synthesis of new DNA or changes in the metabolic activity are determined (38). The direct procedure to analyse cell proliferation is to measure DNA synthesis. During cell proliferation the DNA has to be replicated before the cell is divided into two daughter cells. If labelled DNA precursors are added to the cell culture, cells that are about to divide incorporate the labelled nucleotides into their DNA. The amount of labelled nucleotides incorporated into the cellular DNA is quantified either by liquid scintillation counting (radiolabelled nucleotides) or by a quantitative cellular enzyme immunoassay (BrdU labelled nucleotides). Another alternative parameter to measure the size of a cell population is to determine the metabolic activity of viable cells. Microtiter 


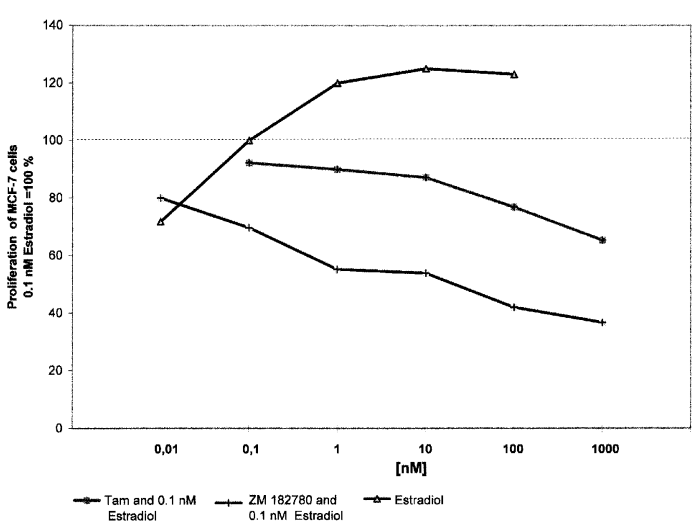

Fig. 3 Analysis of estrogen dependent MCF-7 cell proliferation (Escreen). Test for agonism (estradiol) and antagonism (estradiol $\left[10^{-10} \mathrm{M}\right]$ and tamoxifen or ZM 182780).

assays which use the tetrazolium salt MTT are widely used to quantitate cell proliferation and cytotoxicity (39). In viable cells MTT is reduced to a coloured, water-insoluble formazan salt. After it is solubilized ( $10 \%$ SDS, $0.1 \mathrm{M} \mathrm{HCl}$ ) the formazan formed can easily and rapidly be quantified in a conventional ELISA plate reader. A disadvantage of this method is that a considerable number of substances give positive results in the E-screen without exerting estrogenic activity. In an E-screen only one of the characteristics of an estrogenic compound, its ability to stimulate the growth of hormone-dependent cancer cells, is detectable. The growth of cancer cells can be stimulated in a similar way by cytokines, growth factors, mitogens and nutrients. For this reason the culture conditions of the cells may have a big influence on the obtained results. In addition, it has been demonstrated that different MCF-7 stocks may possess wide variations in regard to their sensitivity to estradiol (40). Using an MCF-7 stock with a low content of estrogen receptor may result in a low sensitivity of the system. In addition there are differences between different MCF-7 stocks in regard to their ability to detect antagonism. This has to be considered in regard to the suitability of this assay to investigate the estrogenicity of a substance. An example for an E-screen and a special issue of this test system is given in Figure 3. The compounds tamoxifen and ZM182780 are both able to antagonise the growth stimulation effect of estradiol in MCF-7 cells. Tamoxifen, a non-steroidal antiestrogen, has been used as a treatment for breast cancer for a quarter of a century. A general problem using tamoxifen as endocrine therapy is the fact that long-term treatment produces drug resistance and that the compound has the potential to induce second malignancies. Specifically, tamoxifen is associated with an increased detection of endometrial cancer. It is believed that one of the main reasons for these disadvantages is based on the fact that this compound has beside its antagonistic also agonistic properties. Tamoxifen is classified as so-called partial agonist. As shown in Figure $\mathbf{3}$ tamoxifen is able to inhibit the growth of MCF-7 breast cancer cells like the pure estrogen antagonist ZM182780 but its capability to stimulate the growth of MCF-7 cells is very low. The agonistic properties of tamoxifen are difficult to detect in MCF-7 cells. Nevertheless, in other cell types this compound behaves like an agonist and may stimulate gene expression (see Fig. 5), cell proliferation and the growth of the uterus very efficiently.

\section{Reporter Gene Assays}

In a reporter gene assay the capability of a substance to activate the transcription of an estrogen-sensitive promotor is analysed (41). Eukaryotic cells, either mammalian cells or yeast cells, are transfected with an expression vector encoding the human estrogen receptor and a reporter gene vector. The reporter gene vector is composed of an estrogen-sensitive promotor which is linked to a reporter gene (42). This reporter gene encodes for a protein with metabolic activity, which can be easily quantified. The principle mechanism of a reporter gene assay is shown in Figure 4. In cell lines

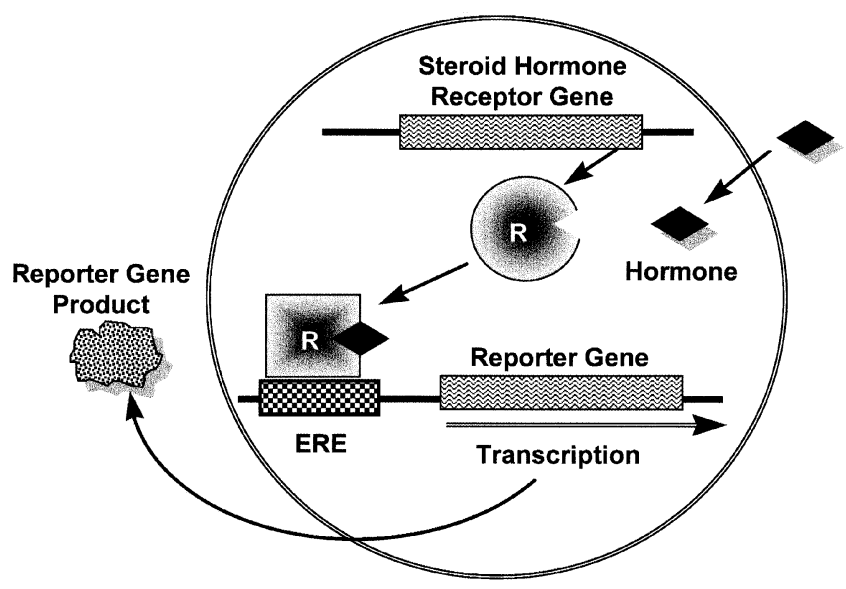

Fig. 4 The functional principle of a reporter gene assay. $\mathrm{R}=$ estrogen receptor, ERE = estrogen responsive element.

expressing an endogenous estrogen receptor, like MCF-7 cells, the cotransfection with an ER-expression vector may not be necessary if the endogenous ER receptor content is sufficient to perform a transactivation assay. In addition to mammalian cells it is also possible to perform transactivation assays in yeasts (43). At the end of the 1980's it was observed that ER work in yeasts analogous to endogenous receptor expressed in mammalian cells (44). The yeast system possess several advantages compared to mammalian cells. Yeasts are easy to culture and in contrast to mammalian cells it is possible to incubate yeasts with non-purified naturally occurring extracts from plants or from the environment (45). Since there is no naturally occurring ER in this species yeast systems are very useful to analyse molecular mechanisms of transcription initiation; in consequence the analysis of the ER-induced transactivation in yeasts is a highly artificial test system. Of course all transactivation systems, including those which are performed in mammalian cells are artificial in regard to the "real world" in the animal or human. The results show a wide variation, depending on the reporter gene used, promotor and cell line. Nevertheless, reporter gene assays are very useful and powerful tools to identify substances which are able to activate estrogen dependent transcription and to determine their estrogenic potency. Reporter gene assays are suitable to characterise the agonistic and antagonistic properties of a substance (Fig. 5). Finally the analysis of a high number of substances in a short period of time is possible. 

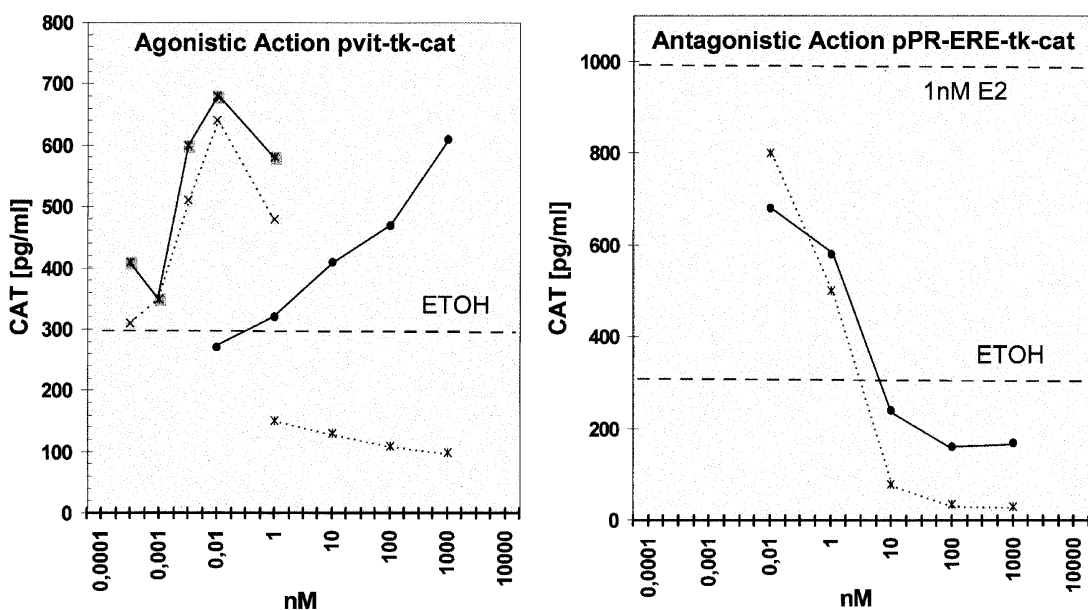

Fig. 5 Analysis of the agonistic and antagonistic potency of estrogens (estradiol, ethinylestradiol) and antiestrogens (tamoxifen and ZM 182780) in two different reporter gene systems. Note the pure antagonistic properties of ZM 182780 in contrast to the partial agonistic properties of tamoxifen. pvit-tk-cat = cat reporter gene with the promotor of the vitelogenin gene. PPR-EREtk-cat $=$ cat reporter gene with an synthetic promoter containing the ERE of the progesterone receptor gene.

\begin{tabular}{ll}
$\times$ Estradiol & $*$ Ethinylestradiol \\
- OH-Tamoxifen & $*$ ZM182780 \\
\hline
\end{tabular}

\section{Analysis of the Regulation of Endogenous Genes in Cell Lines}

The analysis of the regulation of endogenous estrogen sensitive genes is one of the most valid procedures to characterise the estrogenicity of a substance in vitro. Whereas in a reporter gene assay the expression of artificial gene constructs in an artificial environment is analysed, endogenous estrogen sensitive genes are imbedded in their native environment (46). The genes are integrated in the genome, in their natural copy number at the appropriate position on the chromosome. They possess complete promotors and they are imbedded in the complex regulatory machinery of the cell. The analysis of the expression of endogenous genes in different types of organotypic cell lines offers the possibility to recognise organ selective effects of substances. An example for such an attempt is demonstrated in Figure 6. A disadvantage of this method is the tedious experimental procedure, which is necessary to perform such an assay. However, if modern molecular biological methods like semiquantitative PCR are used $(47,48)$ it is possible to achieve results in a comparable time and to standardise the test systems. In Figure 7 an example for a PCR analysis of endogenous gene expression of estrogen sensitive genes is given $(47,49)$.

\section{Test Systems for the Prediction of Non-Classical Estrogen Action}

Recently it has been demonstrated that estrogens can act in many examples via so-called "non-classical" mechanisms (50). A good example is the regulation of interleukin-6 (IL-6) a multifunctional cytokine by estradiol. IL- 6 is secreted by osteoblasts and appears to be a key molecule in the osteoporotic process (51). Consistent with histomorphometric data from humans, there is evidence from studies in animal models suggesting that a critical cellular change caused by the loss of ovarian, as well as testicular function is an increase in osteoclastogenesis. This change is apparently mediated by an increase in the production of the osteoclastogenic cytokine interleukin- 6 by cells of the bone marrow, which follows the removal of an inhibiting control of estrogens or androgens on IL-6. The inhibition of IL-6 by estradiol is an important molecular mechanism which can explain the epidemiologic data indicating the ability of estrogen replacement therapy to prevent bone loss in postmenopausal osteoporotic women (52). To study the regulation of IL-6 expression by an estrogenic substance offers the possibility to investigate its bone protective potency. Therefore, several in vitro test systems, including transactivation tests, have been developed to study
A

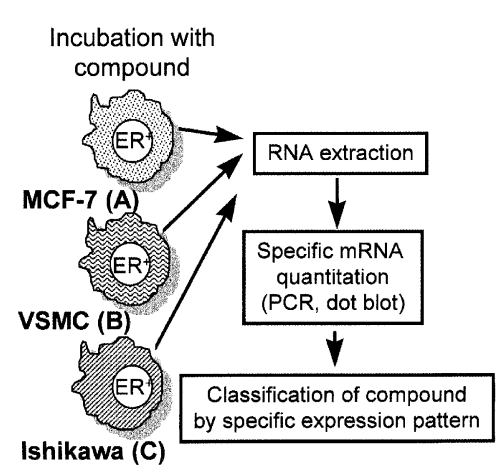

B

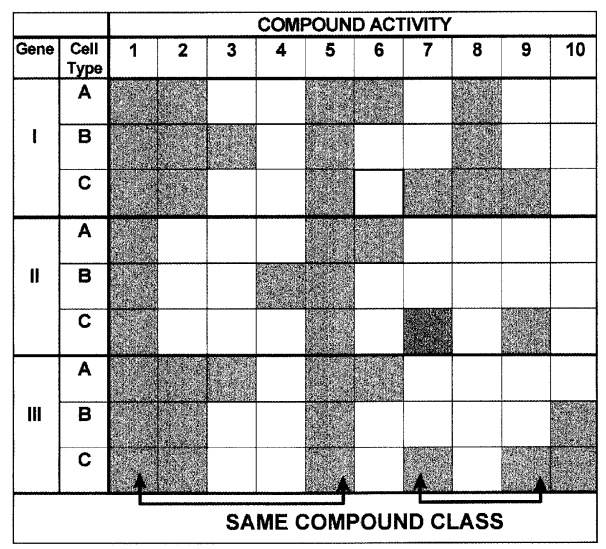

Fig. 6 Analysis of endogenous gene expression in different organotypic cell lines to recognise organ selective estrogenic effects of substances. A. Principle of the assay. MCF-7 = breast cancer cell line, VSMC = vascular smooth muscle cells, Ishikawa $=$ endometrium carcinoma cell line. B. Characterisation of compounds by the analysis of their ability to stimulate the transcription ( $\square$ gene expression, $\square$ no gene expression) of three different genes (I, II, III) in three different cell lines (A, B, C). 
(A) IGFBP-1

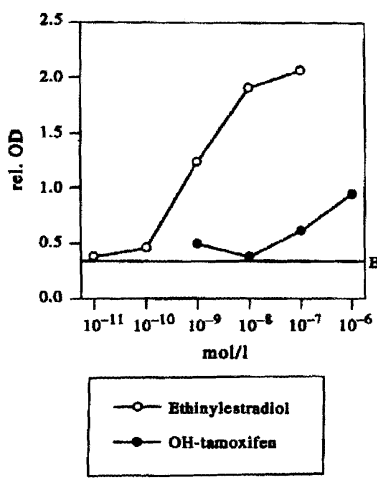

(B) MAP

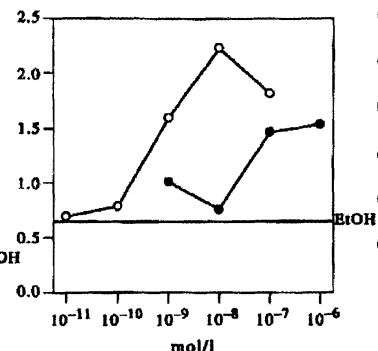

$\mathrm{mol} / \mathrm{l}$
(C) CaBP9k

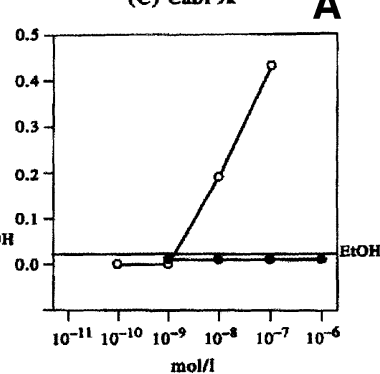

A

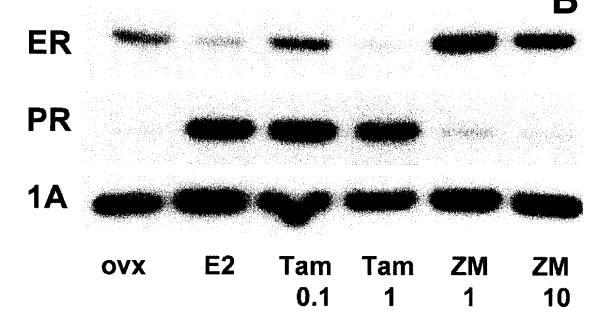

Fig. 7 Analysis of the ability of different estrogens to regulate the endogenous gene expression. A. Analysis of the dose dependent regulation of Insulin-like-growth factor-1 (IGFBP-1), Major acute phase protein (MAP) and Calbindin 9 (CaBP9k) mRNA expression by tamoxifen and ethinylestradiol in Fe 33 liver cells using northern blot technique (47). B. Analysis of the stimulation of the expression of ER and PR mRNA by estradiol (E2) tamoxifen (Tam) and ZM 182780 (ZM) in the rat vascular tissue using semiquantitative PCR (49).

the regulation of IL-6 expression (53). In this context special emphasis should be given to the fact that the inhibition of IL6 expression by estradiol is an indirect action via the transcription factor NFKB (54), which involves the ER but not its interaction with responsive elements on the DNA. The principle of an IL-6 assay is demonstrated in Figure $\mathbf{8}$.

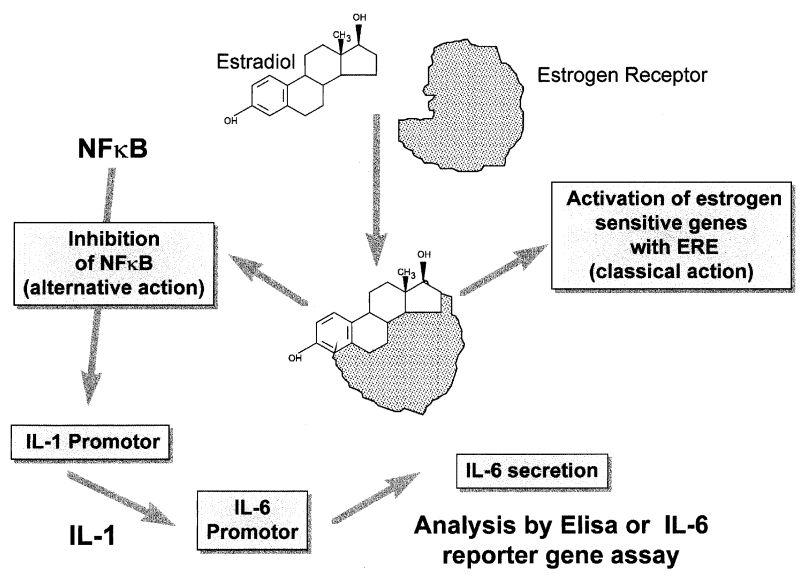

Fig. 8 Analysis of the IL- 6 secretion to characterise the potential bone specific estrogenic action of a substance.

\section{Summary and Conclusions}

Today in vitro test systems are very powerful and necessary tools to identify and characterise the estrogenic potency of substances. The use of suitable in vitro test systems offers the possibility to get first clues whether a substance may act like an estrogen but the limitations of such in vitro systems always have to be considered. In Table $\mathbf{3}$ a summary of advantages and issues of the presented test systems is given. None of the discussed test systems is able to detect all important properties of an estrogenic substance. Neither the binding of a substance to the estrogen receptor nor its ability to stimulate the growth of MCF-7 cells for itself does mean that the substance has estrogenic potency. Therefore, there is always the need to use a suitable panel of different in vitro test systems to characterise a substance (55). However, it is necessary to point out that even a combined use of several in vitro test systems is not able to predict the occurring action of a substance in the organism. In vivo a substance is exposed to multiple metabolic transformations and integrated in complex endocrine interactions. In vitro test systems are only appropriate to indicate if a substance is estrogenic. They are suitable to identify most promising compounds in drug finding programs. For the validation of the results of the in vitro models and the real prediction of the estrogenic potency

Table 3 Advantages and issues of in vitro test systems for the detection of estrogenicity.

\begin{tabular}{|c|c|c|c|}
\hline Assay & Analysis of & Advantage & Issue \\
\hline Receptor binding & Receptor affinity & Easy to perform & $\begin{array}{l}\text { No distinguishing between agonistic and } \\
\text { antagonistic activity }\end{array}$ \\
\hline E-screen & $\begin{array}{l}\text { Ability to stimulate growth of } \\
\text { hormone dependent cell lines }\end{array}$ & Easy to perform and cheap & $\begin{array}{l}\text { Only growth stimulating substances are } \\
\text { detectable } \\
\text { Different MCF-7 stocks show a wide varia- } \\
\text { tion in regard to their sensitivity to estradiol }\end{array}$ \\
\hline Reporter gene assay & $\begin{array}{l}\text { Ability to activate transcription } \\
\text { of reporter gene constructs }\end{array}$ & $\begin{array}{l}\text { Easy to analyse a high amount } \\
\text { of substances }\end{array}$ & $\begin{array}{l}\text { Artificial, results depend on cell line and } \\
\text { used construct }\end{array}$ \\
\hline
\end{tabular}

Endogenous gene expression (mRNA)
Ability to stimulate expression of endogenous genes
Can be used for the analysis of non classical estrogenic action Non artificial

Possibility to study tissue specific effects 
a final analysis in animal models is always necessary. As the "drug hunters" in compound finding in pharmaceutical companies put this conclusion in their saying "in vivo veritas".

\section{Acknowledgements}

The authors wish to thank Dr. Karl-Heinrich Fritzemeier (Schering AG, Berlin) and Prof. Dr. H. Winterhoff (University of Münster) for their helpful comments and encouragement.

\section{References}

${ }^{1}$ Harborne, J. B. (1979) in: Rosenthal, G. A., Janzen, D. H., Academic Press, New York, 619-655.

2 Adlercreutz, H., Fotsis, T., Heikkinen, R., Dwyer, J. T., Woods, M., Goldin, B. R., Gorbach, S. L. (1982) Lancet 2, 1295-1299.

3 Adlercreutz, H., Mousavi, Y., Clark, J., Hockerstedt, K., Hamalainen, E., Wahala, K., Makela, T., Hase, T. (1992) J. Steroid. Biochem. Mol. Biol. 41, 331 - 337.

${ }^{4}$ Adlercreutz, H. (1988) in: (Rozen P., ed.), Frontiers of Gastrointestinal Research, 14, 165 - 176 .

${ }^{5}$ Adlercreutz, H., Hockerstedt, K., Bannwart, C., Bloigu, S., Hamalainen, E., Fotsis, T., Ollus, A. (1987) J. Steroid. Biochem. 27, 11351144.

${ }^{6}$ Setchell, K. D., Borriello, S. P., Hulme, P., Kirk, D. N., Axelson, M. (1984) Am. J. Clin. Nutr. 40, 569-578.

7 McLachlan, J. A., Newbold, R. R. (1987) Environ. Health Perspect. $75,25-27$.

${ }^{8}$ Setchell, K. D., Gosselin, S. J., Welsh, M. B., Johnston, J. O., Balistreri, W. F., Kramer, L. W., Dresser, B. L., Tarr, M. J. (1987) Gastroenterology 93, 225-233.

${ }^{9}$ Horwitz, K. B., Koseki, Y., McGuire, W. L. (1978) Endocrinology $103,1742-1751$.

10 Henderson, B. E., Ross, R. K., Paganini-Hill, A., Mack, T. M. (1986) Am. J. Obstet. Gynecol. 154, 1181-1186.

11 Turner, R. T., Riggs, B. L., Spelsberg, T. C. (1994) Endocr. Rev. 15, $275-300$.

12 Fillit, H., Weinreb, H., Cholst, I., Luine, V., McEwen, B., Amador, R., Zabriskie, J. (1986) Psychoneuroendocrinology 11, 337 - 345.

13 Colditz, G. A. (1993) Cancer 71, 1480-1489.

14 Jensen, E., Jacobson, H. (1962) Rec. Prog. Horm. Res. 18, 387.

15 Jensen, E. V., Suzuki, T., Kawashima, T., Stumpf, W. E., Jungblut, P. W., DeSombre, E. R. (1968) Proc. Natl. Acad. Sci. U.S.A. 59, 632 638.

16 King, W. J., Greene, G. L. (1984) Nature 307, 745 - 747.

17 Rossini, G. P. (1994) J. Theor. Biol. 166, 339-353.

18 Smith, C. L., Conneely, O. M., O'Malley, B. W. (1993) Proc. Natl. Acad. Sci. U.S.A. 90, 6120-6124.

19 Wang, Y., Miksicek, R. J. (1991) Mol. Endocrinol. 5, 1707-1715.

20 Gronemeyer, H. (1992) FASEB J. 6, 2524-2529.

21 Grody, W. W., Schrader, W. T., O'Malley, B. W. (1982) Endocr. Rev. $3,141-163$.

22 Liebermann, B. A. (1997) Crit. Rev. Eukaryot. Gene Expr. 7, 43 - 59.

23 Gronemeyer, H., Benhamou, B., Berry, M., Bocquel, M., Gofflo, D. Garcia, T., Lerouge, T., Metzger, D., Meyer, M., Tora, I., Vegezac, A., Chambon, P. (1992) J. Steroid Biochem. 43, 217-221.

24 Welshons, W. V., Lieberman, M. E., Gorski, J. (1984) Nature 307, $747-749$.

25 Furlow, J. D., Murdoch, F. E., Gorski, J. (1993) J. Biol. Chem. 268, $12519-12525$.

${ }^{26}$ Ing, N. H., Beekman, J. M., Tsai, S. Y., Tsai, M. J., O'Malley, B. W. (1992) J. Biol. Chem. 267, 17617-17623.

27 Truss, M., Bartsch, J., Schelbert, A., Hache, R. J., Beato, M. (1995) EMBO J. 14, $1737-1751$.

28 Scheidereit, C., von der Ahe, D., Cato, A. C., Wenz, M., Suske, G., Carlson, C., Bosshard, H., Westphal, H. M., Beato, M. (1989) Endocr. Res. 15, 417-440.
${ }^{29}$ Aronica, S. M., Kraus, W. L., Katzenellenbogen, B. S. (1994) Proc. Natl. Acad. Sci. U.S.A. 91, 8517-8521.

30 Weigl, N. (1996) Biochem. J. 319, 657 - 667.

31 Blobel, G. A., Sieff, C. A., Orkin, S. H. (1995) Mol. Cell. Biol. 15, 3147-3153.

32 Power, R. F., Conneely, O. M., O'Malley, B. W. (1992) Trends Pharmacol. Sci. 13, 318-323.

33 Rossini, G. P. (1984) J. Theor. Biol. 108, 39-53.

34 Moss, R. L., Gu, Q., Wong, M. (1997) Recent Prog. Horm. Res. 52, $33-68$.

35 Baulieu, E. E., Kelly, P. (Eds.) (1990) Chapmann and Hall, New York, London.

36 Kilbourn, M. R., Zalutsky, M. R. (1985) J. Nucl. Med. 26, 655-662.

37 Soto, A. M., Sonnenschein, C., Chung, K. L., Fernandez, M. F., Olea, N., Serrano, F. O. (1995) Environ. Health Perspect. 103, 113 - 122.

38 Trauth, B. C., Keesey, J. (1996) Boehringer Mannheim.

39 Vistica, D. T., Skehan, P., Scudiero, D., Monks, A., Pittman, A., Boyd, M. R. (1991) Cancer Res. 51, 2515 - 2520.

${ }^{40}$ Villalobos, M., Olea, N., Brotons, J. A., Olea-Serrano, M. F., Ruiz de Almodovar, J. M., Pedraza, V. (1995) Environ. Health Perspect. 103, $844-850$.

41 Bronstein, I., Fortin, J., Stanley, P. E., Stewart, G. S., Kricka, L. J. (1994) Anal. Biochem. 219, 169-181.

42 Burch, J. B., Evans, M. I., Friedman, T. M., O'Malley, P. J. (1988) Mol. Cell. Biol. 8, 1123- 1131 .

43 Wagner, B. L., McDonnell, D. P. (1996) in: Estrogens, Progestins and their Antagonists, Vol. 2, (Pavlik, E. J., ed.), Birkhäuser, Berlin.

44 Metzger, D., White, J. H., Chambon, P. (1988) Nature 334, 31 - 36.

45 Arnold, S. F., Robinson, M. K., Notides, A. C., Guillette, L. J., Mc Lachlan, J. A. (1996) Environ. Health Perspect. 104, 544 - 548.

46 Jorgensen, M., Hummel, R., Bevort, M., Andersson, A. M., Skakkebaek, N. E., Leffers, H. (1998) APMIS 106, 245-251.

47 Diel, P., Walter, A., Fritzemeier, K. H., Hegele-Hartung, c., Knauthe, R. (1995) J. Steroid Biochem. Mol. Biol. 55, 363 - 373.

${ }^{48}$ Kauser, K., Sonnenberg, D., Diel, P., Rubanyi, G. M. (1998) Br. J. Pharmacol. 123, 1089-1096.

49 Knauthe, R., Diel, P., Hegele-Hartung, C., Engelhaupt, A., Fritzemeier, K. H. (1996) Endocrinology 137, 3220 - 3227.

50 Brann, D. W., Hendry, L. B., Mahesh, V. B. (1995) J. Steroid Biochem. Mol. Biol. 52,113 - 118 .

51 Manolagas, S. C., Bellido, T., Jilka, R. L. (1995) Int. J. Immunopharmacol. 17, 109- 116 .

52 Horowitz, M. C. (1993) Science 260, 626-627.

53 Galien, R., Evans, H. F., Garcia, T. (1996) Mol. Endocrinol. 10, 713 722.

54 van der Burg, B., van der Saag, P. T. (1996) Mol. Hum. Reprod. 2, $443-438$

55 Klotz, D. M., Beckman, B. S., Hill, S. M., McLachlan, J. A., Walters, M. R., Arnold, S. F. (1996) Environ. Health Perspect. 104, 10841089.

\section{Dr. Patrick Diel}

Institut für Experimentelle Morphologie

Deutsche Sporthochschule Köln

Carl Diem-Weg 6

D-50933 Köln

Germany

E-mail: diel@hrz.dshs-koeln.de

Fax: + 49 221-4995 765 